\title{
First report of Hygrophorus pudorinus (A wild edible Mushroom) from India with macro- and micro-morphology
}

\author{
Dyutiparna Chakraborty ${ }^{1}$, Sobhan Kumar Mukherjee ${ }^{2}$ and Kanad Das ${ }^{1 凶}$ \\ ${ }^{1}$ Cryptogamic Unit, Botanical Survey of India, P.O. Botanic Garden, Howrah - 711103, India \\ ${ }^{2}$ Department of Botany, University of Kalyani, Kalyani - 741235, Nadia, India \\ 凶Corresponding author: daskanadbsi@gmail.com
}

\section{भारत से हाइग्रोफोरस पुडोरिनस (वन्य खाद्य मशरूम) के बृहद एवं सूक्ष्माकारिकी के साथ प्रथम अभिलेख} दयूतिपर्णा चक्रवर्ती, सोभन कुमार मुखर्जी एवं कनाद दास

\section{सारांश}

हाइग्रोफोरस पुडोरिनस जिसे सिक्किम के उप उच्च हिमालयी क्षेत्र से संग्रहित किया गया है, को प्रथम बार भारत के लिये अभिलेखित कर वर्णित एवं चित्रित किया गया है। इस शोध पत्र में इस जाति की सबद्ध जातियों के साथ इसका तुलनात्मक अध्ययन भी दिया गया है।

\section{ABSTRACT \\ Hygrophorus pudorinus which is collected from subalpine Himalaya of Sikkim is described and illustrated for the first time from India. Comparisons with the allied taxa are also provided.}

Keywords: Hygrophoraceae, Macrofungi, Sikkim, Taxonomy

\section{INTRODUCTION}

Members of the genus Hygrophorus Fr. are mainly characterised by their waxy nature of pileus and lamellae, elongated basidia, smooth spores, bilateral hymenophoral trama, and occurrence of ectomycorrhizal associates of higher plants. In India, along with other members of the family Hygrophoraceae, this genus was also not explored thoroughly and only few sporadic reports were made by Berkeley $(1856,1882)$, Sharma \& Munjal (1977). During a recent macrofungal foray to different parts of East district of Sikkim (a small Himalayan state) in 2015 one of us (DC) encountered an edible member of Hygrophoraceae. Detailed macro- and micro-morphological studies followed by literature survey revealed its conspecificity with Hygrophorus pudorinus (Fr.) Fr., a species originally reported from North America. In this manuscript $H$. pudorinus is reported for the first time from India with macro- and micro-morphological illustrations and comparisons with allied taxa. 


\section{METHODS}

Macromorphological characters, macrochemical colour tests (with the application of $10 \% \mathrm{KOH}, \mathrm{FeSO}_{4}$ and Guaiacol) and habitat details were recorded from fresh basidiomata in the basecamp or field. Specimens were dried with a portable field dryer. Photographs of fresh basidiomata and microphotographs were captured with a Canon SX 120 and Nikon-DS-Ril (dedicated to Nikon Eclipse Ni compound microscope) cameras respectively. Color codes and terms mostly follow Methuen Handbook of Color (Kornerup \& Wanscher 1978). Subsequently micromorphological features were recorded with the aid of a compound microscope (Nikon Eclipse $\mathrm{N} i$-U) from free-hand sections of dry basidiomata mounted in $5 \% \mathrm{KOH}$, or stained in a mixture of $5 \% \mathrm{KOH}$ and phloxin and mounted in $30 \%$ glycerol or distilled water. Drawings were made with a drawing tube (attached to Nikon-DS-Ri1) at 1000× magnification. Basidium length excludes length of sterigmata. Spore-measurements were recorded in profile view from thirty basidiospores. Spore-size measurements and length/ width ratios $(\mathrm{Q})$ are given as: minimum-mean-maximum. Herbarium acronym follows Holmgren \& al. (1990).

Hygrophorus pudorinus (Fr.) Fr., Anteckn. Sver. Ätl. Svamp.: 46 (1836).

Agaricus pudorinus Fr., Syst. mycol. (Lundae) 1: 33 (1821). Hygrophorus pudorinus f. pallidus (A.H. Sm. \& Hesler) Hesler \& A.H. Sm. North American Species of Hygrophorus: 337 (1963). Hygrophorus pudorinus var. pallidus (A.H. Sm. \& Hesler) Bon, Docums Mycol. 7(nos 27-28): 37 (1977). Hygrophorus pudorinus var. subcinereus (A.H. Sm. \& Hesler) Hesler \& A.H. Sm., North American Species of Hygrophorus: 338 (1963).

Pileus 16-70 mm. diam.; convex to sub pyramidal or pyramidal; surface scaly, glutinous, pitted or scrobiculate, in combination of pale orange to light orange (5A3-4), brownish orange or greyish red (7C5-4 or 8C5) or darker, centre darker than the rest. Lamellae narrowly adnate to subdecurrent, close (10/cm at pileus-margin), often forked, greyish orange (5B4); lamellulae present, in 2 series. Stipe 40-70 × 12-43 mm, central, white, slowly becoming concolorous with pileus; surface slightly floccose, white at apex; with minute striations throughout that frequently anastomose surrounding pits, especially towards base. Context solid in pileus and stipe. Spore print not found.

Basidiospores 7.2-8.2-9.6 × 4.4-4.8-5.4 $\mu \mathrm{m}(\mathrm{n}=20$, $\mathrm{Q}=1.50-1.67-2.08$ ), ellipsoid to elongate; smooth. Basidia 45-65 × 8-10 $\mu \mathrm{m}$, 4-spored, narrowly clavate to subcylindric. Pleurocystidia and cheilocystidia absent. Lamellae-edge fertile, concolorous. Hymenophoral trama divergent. Pileipellis $150-320 \mu \mathrm{m}$ thick, ixotrichoderm to ixocutis; hyphae septate, clamped, terminal cells cylindrical, subfusoid with mostly rounded apex. Stipitipellis up to $130 \mu \mathrm{m}$ thick, trichoderm with erect, septate, clamped hyphae; terminal cells 5.3-7.5 $\mu$ m wide, mostly cylindrical with subfusoid to appendiculate rounded apex.

Habitat: Scattered to gregarious under coniferous tree of subalpine mixed (broad leaf and conifer) forest

Distribution: North East America, Europe, India.

Specimens examined: India: Sikkim, East District, Memainchu, 3601m, N 27²1'00.6” E88 49'30.9”, 06.07.2015, D. Chakraborty, DC 15-018 (CAL); Kyangnosla, $3352 \mathrm{~m}, \mathrm{~N} 27^{\circ} 22^{\prime} 21.0^{\prime \prime} \mathrm{E} 88^{\circ} 46^{\prime} 31.1$ ', 07.07.2015, $D$. Chakraborty, DC 15-024 (CAL).

Note: Hygrophorus pudorinus (Fr.) Fr. is well distributed in Notrh East America (Hesler and Smith 1963, Bessette \& al. 2012) and Europe (Knudsen \& Vesterholt 2012, Breitenbach \& Kränzlin 1991) where they commonly known as "Blushing Hygrophorus" or "Turpentine Waxcap". Its existence was merely known from Himachal Pradesh without any morphological description or illustration (Kumar \& al. 1990). Repeated macrofungal forays undertaken by Botanical Survey of India in recent years uncovered this mushroom species which is highly appreciated by the local people of Sikkim and taken with delicacy.

According to Hesler \& Smith (1963) H. pudorinus is placed under subgen. Hygrophorus as its hymenophoral trama is not interwoven and basidiospores are inamyloid. Macro- and micro-morphological characters of Indian material is on conformity with its American counterpart except the pileus of Indian specimen which were slightly smaller in comparison to American specimens (Hesler \& Smith 1963). Moreover, presence of the combination of characters like, dry stipe, distinct coloration (buff to salmon) of pileus, thick and soft stipe, divergent hymenophoral trama confirms its taxonomic placement under series Pudorini of subsection Camarophylli under the section Hygrophorus (Hesler \& Smith 1963). While considering the recent phylogeny of the family Hygrophoraceae, $H$. pudorinus is now well placed under tribe Hygrophoreae of subfamily Hygrophoroideae (Lodge \& al. 2014).

Morphologically and phylogenetically allied species of $H$. pudorinus are $H$. poetarum R. Heim, $H$. secretanii Henning and H. russula (Schaeff.) Kauffman. But, Hygrophorus poetarum differs from $H$. pudorinus by its 

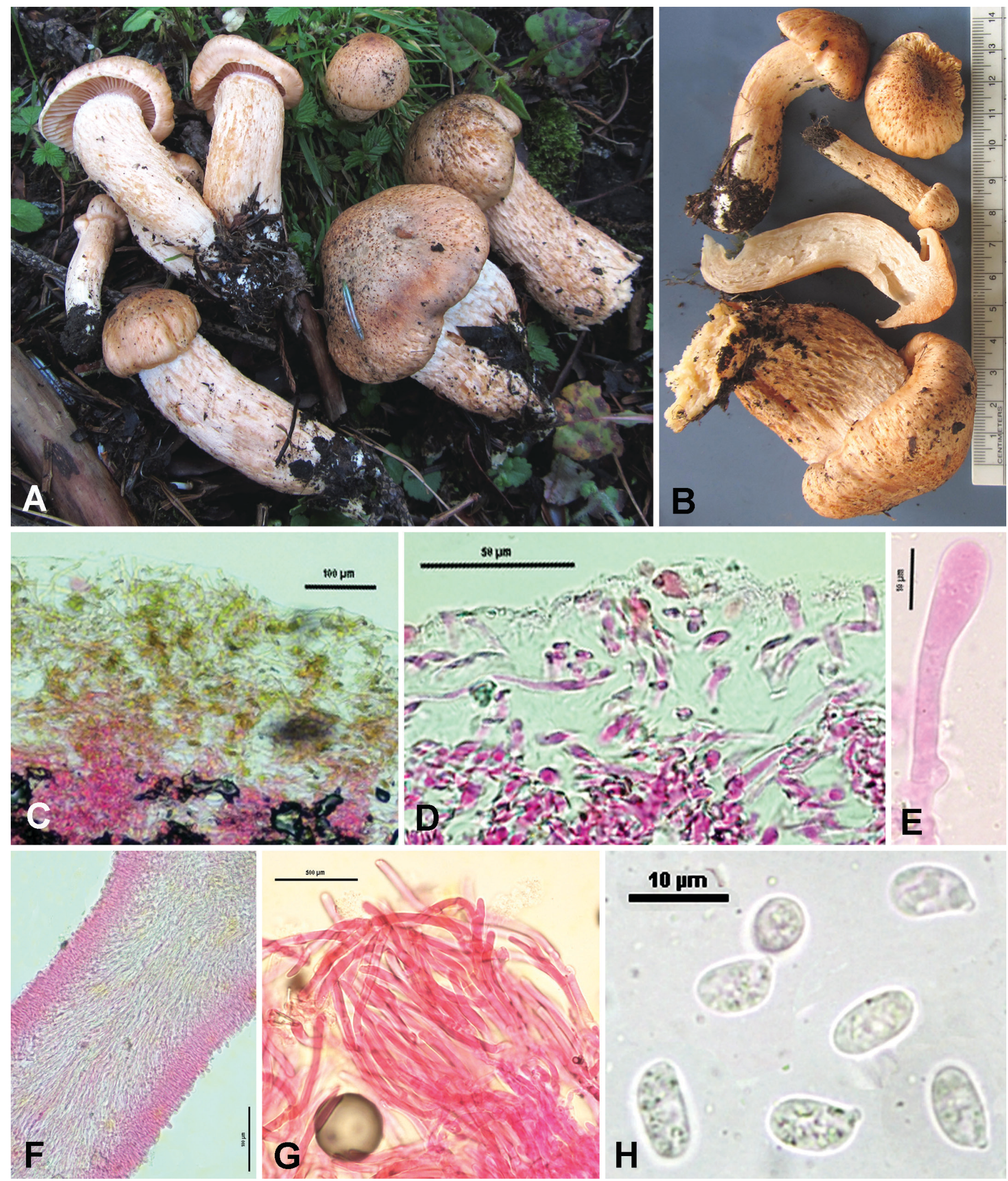

Fig. 1: A. \& B. Fresh young and mature basidiomata; C. \& D. Pileipellies; E. Basidiole with basal clamp; F. Lamellar trama; G. Stipitipellis; H. Basidiospores. Bars = C \& F: $100 \mu \mathrm{m}$, D: $50 \mu \mathrm{m}, \mathrm{E} \& \mathrm{H}: 10 \mu \mathrm{m}, \mathrm{G}: 500 \mu \mathrm{m}$. 


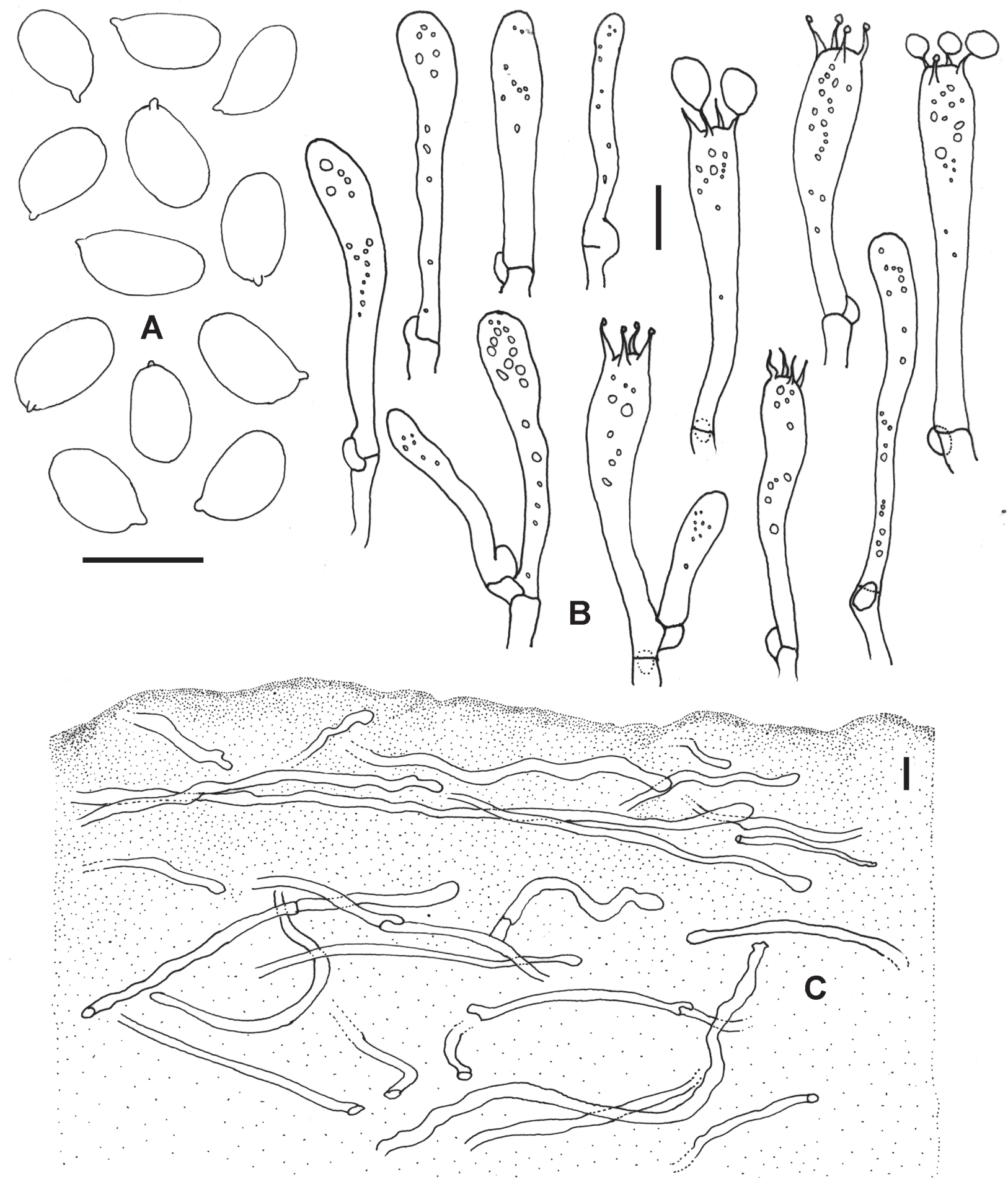

Fig. 2: A. Basidiospores; B. Basidia and Basidioles; C. Pileipellis. Bars = A \& B: $10 \mu \mathrm{m}$, C: $25 \mu \mathrm{m}$.

occurrence in association with Fagus sp., presence of pileus with umbo and decurrent gills (Hesler \& Smith 1963, Breitenbach \& Kränzlin, 1991). Hygrophorus russula is separated by its pruinose stipe apex, reddening of context on bruising, gills with purplish red spots, and occurrence under Quercus sp. (Bessette \& al. 2012). Hygrophorus secretanii is quite distinct by its occurrence under Picea sp., having bitter almond odour, distant gills and presence of $4-\& 2$-spored basidia (Knudsen \& Vesterholt 2012). 


\section{ACKNOWLEDGEMENTS}

Authors are thankful to the Director, Botanical Survey of India (BSI), Kolkata, for providing facilities during this study. We thank the entire forest department of Sikkim, Gangtok and the scientist-in-charge, BSI, Gangtok, for arranging permits to survey in different areas of East Sikkim for one of us (DC).

\section{REFERENCES}

BERKELEY, M.J. 1852. Decades of Fungi, decade XXXIX, XL: Sikkim and Khassya Fungi. Hooker's Journal of Botany 4: $130-142$.

BERKELEY, M.J. 1856. Decades of fungi, Decas 1-62 Nos. 1-620. Hooker's Journal of.Bot. 3-8: 1844-1856.

BESSETTE, A.E., W.C. ROODY, W.E. STURGEON AND A.R. BESSETTE 2012. Waxcap mushrooms of Eastern North America. Suracuse University press, Suracuse, New York. $179 \mathrm{pp}$.

BREITENBACH, J. AND F. KRÄNZLIN 1991. Fungi of Switzerland, vol. 3. Mykologia Lucerne, Switzerland. $361 \mathrm{pp}$.

HESLER, L.R. AND A.H. SMITH 1963. North American species of Hygrophorus. Knoxville. 416 pp.

HOLMGREN, P.K., N.H. HOLMGREN AND L.C. BARNETT 1990. Index Herbariorum. Part I: Herbaria of the world, $86^{\text {th }}$ ed. Bronx: New York Botanical Garden, USA. $693 \mathrm{pp}$.

KNUDSEN, H. AND J. VESTERHOLT 2012. Funga Nordica: Agaricoid, boletoid, clavarioid, cyphelloid and gastroid genera. Nordsvamp, Denmark. 1083 pp.

KORNERUP, A. AND J.H. WANSCHER 1978. Methuen handbook of color, 3rd Ed. Eyre Methuen Ltd., London, UK. 252 pp.

KUMAR, A., T.N. LAKHANPAL AND S.L. STEPHENSON 1990. Ecological studies of some macrofungi in the northwestern Himalayas. Nova Hedwigia 50: 535-547.

LODGE, D.J., M. PADAMSEE, P.B. MATHENY, M.C. AIME, S.A. CANTRELL, D. BOERTMANN, A. KOVALENKO, A. VIZZINI, B.T.M. DENTINGER, P.M. KIRK, A.M. AINSWORTH, J.-M. MONCALVO, R. VILGALYS, E. LARSSON, R. LÜCKING, G.W. GRIFFITH, M.E. SMITH, L.L. NORVELL, D.E. DESJARDIN, S.A. REDHEAD, C.L. OVREBO, E.B. LICKEY, E. ERCOLE, K.W. HUGHES, R. COURTECUISSE, A. YOUNG, M. BINDER, A.M. MINNIS, D.L. LINDNER, B. ORTIZ-SANTANA, J. HAIGHT, T. LÆSSØE, T.J. BARONI, J. GEML AND T. HATTORI 2014. Molecular phylogeny, morphology, pigment chemistry and ecology in Hygrophoraceae (Agaricales). Fungal Diversity 64: 1-99. http://dx.doi.org/10.1007/ s13225-013-0259-0

SHARMA, A.D. AND R.L. MUNJAL 1977. Some fleshy fungi from Himachal Pradesh. Indian J. Mush. 3: 18-21. 